\title{
INDIGENOUS COMMUNITY, CUSTOMARY LAW AND MULTICULTURALISME IN INDONESIA
}

\author{
Zaenuddin Hudi Prasojo \\ Pontianak State College of Islamic Studies
}

\begin{abstract}
The awareness of awakening and efforts in reviving the customary law of indigenous communities in Indonesia has been going on for a long time, at least since the end of the reign of the New Order Regime. Customary law as one of the authentic capital of indigenous communities is a reflection of the existence of multicultural principles that have actually existed and been part of the Indonesian society. This work explores the case of cutomary law in West Kalimantan on Katab Kebahan's practices in Melawi which is potential to be included to the National law. The role of customary law in the life of the multicultural society, like West Kalimantan society, in the modern era should be aligned with the history of the Unitary State of the Republic of Indonesia which was founded by the best children of the nations that agreed to establish a state based on the supremacy of law. Customary law is part of the state law. Therefore, there is s need to think of a proper format for the position and the role of customary law in the Indonesian legal system for the prosperity of society based on equality before the law and justice in accordance with the ideals of the nation. This paper suggests that, as an alternative as to where we might put the position of customary law in a multicultural nation today, we can take the example from patterns made by several countries that have adopted Restorative Justice systems with the main principles that the law is a device to resolve the problems in a just and fair way and with the awareness to return all the problems to the perspective of the law for the common good.
\end{abstract}

Key words: cutomary law, mulitcultural society, restorative, justice

\section{INTRODUCTION}

The phenomenon of multicultural society is, in fact, a natural reality that occurs in the process of interactions between people from different cultural groups in the life of modern society. This is driven by the growing level of human knowledge and the need of the development of human civilization. Therefore, the movement of multiculturalism has actually appeared for a long time, characterized by the globalization era in which humans are increasingly easy to interact globally both physically and non-physically such as in cyber world. In the United States, a multicultural society has even become part of the 
history of the country where various cultures have existed since the Europeans, led by Colombus, arrived there for the first time. In Indonesia, the plurality of cultures is inseparable from the history of the nation. The founders of the country even agreed on a symbol of a multicultural nation that is familiar to all Indonesians, i.e. Bhinneka Tunggal Ika which means Unity in Diversity.

On the path of its history, the people of Indonesia have experienced a variety of dynamics that drove them into the cultural attitudes that vary according to political conditions. In the era of the Old Order, the plurality managed to awaken the spirit of struggle to resolve all the problems faced the nation. Then, in the New Order era, there was a very sharp political shift that changed the attitude of the multicultural nation where the centralized government oppressed the local cultures that existed in different areas outside of the Java island. During the Reform era, the multicultural movement under the administration of President Abdurrahman Wahid (Gus Dur), was back to find its way. Since then, it has inspired the emergence of movements of minorities including the Adat (a set of cultural norms, values, customs and practices found among specific ethnic groups) communities in various parts of the country marked by the establishment of the Alliance of Adat Society of Nusantara (AMAN).

Before the era of the rise of the indigenous community, the Adat community was hardly a subject of discussion in the international sphere. Today, the discussion of local communities is entering into a new chapter in the modern world. The movements of Adat peoples to participate in the international scene were marked the emergence of activism from different parts of the world, which was initiated by the activists of the indigenous peoples of South America that conveyed voice of the indigenous community's rights. These movements was later brought to the attention of the world in New York City, where the representatives of the indigenous movement demand for representation of indigenous community groups in the institution that becomes the symbol of the world's community, the United Nations (UN). Then in the early 19th century, a Special Commission was formed for local communities to accommodate their interests and to discuss related issues around the world. AMAN is the answer the issues of Adat peoples in Indonesia.

Indigenous peoples are faced with various challenges in the face of the development of the contemporary world. Among them are the issues of environmental sustainability, cultural environment and the natural environment such as forests, rivers and land which are crucial to the survival of local communities. Meanwhile, the cultural heritage of their ancestors that strongly depends on the availability of natural resources requires the natural 
resource sustainability. On the other hand, the economic needs are increasing as a result of global competition that has even reached remote corners of the villages, including those in the rural areas in West Kalimantan. The influence of economic power from the outside through the agents of globalization has put a lot of pressure on traditional communities. These communities are facing difficult choices but are also required to endure the pressure (Bamba, 2004; Abdullah, 2006).

The question that arises then is why does the indigenous movement emerge and how do the indigenous peoples respond to the influx of globalization with all the attributes including the movement of multiculturalism? This paper tries to explain the position of customary law which is the property of the indigenous communities in responding to the movement of the multiculturalism that is increasingly familiar to almost every society all over the world, including that in West Kalimantan, Indonesia.

\section{CUSTOMARY LAW AND INDIGENOUS COMMUNITIES}

Many studies have been done to know and explain the role of indigenous communities in modern life (Kingsbury, 1998; Bowen, 2000; The Grim, 2001). In addition, studies have also contributed to the scientific and cultural treasures of the world. Some examples here include research on Aboriginal communities in Australia and the contribution of local cultures that give benefits to the modern world. One example of the contribution of a local culture is the system of conflict resolution that uses indigenous institutions with the circle process approach and the principles that return the matter to the parties in dispute on the basis of good faith to resolve the issue (restorative justice) (Zehr, 1990). This system has been adopted by New Zealand as part of the legal system in the country.

In Indonesia, studies on local communities living in rural areas have also been widely conducted, both by researchers from outside as well as by locals. Some examples that can be mentioned here among others are research conducted by Joel S. Kahn (2002) on the cultural development of the rural areas of Indonesia. Kahn provided an in-depth discussion about the culture in the rural areas in Indonesia such as Sulawesi, Papua and Kalimantan. Tania Murray Li also conducted similar research. One of her published papers was about the marginalization of the rural communities in Indonesia including Kalimantan, Sulawesi, Java, Sumatra and Papua (Li, 2001). Local anthropologists also did research in the rural areas. Yekti Maunati's research (2004), for example, focused on the Dayak people of Kalimantan. This research addressed the issue of identity of the Dayak in Central Kalimantan. These studies are interesting 
to analyze because each of them focused on the background and problems faced by the respective regions and saw the complexity of the issues. Among the interesting issues is a discussion about how the dynamics of customary law which is inseparable part of the indigenous peoples or local communities. Said Yacob and Zaenudin Prasojo (2009) explained how the indigenous community of Katab Kebahan revitalized their customary law and traditions in the wake of the fall of the New Order regime to respond to the social and economic conditions of the Katab Kebahan in Melawi.

This paper shows the importance of seeing the reaction of indigenous peoples through strengthening the implementation of customary law as well as the strengthening of indigenous institutions in responding to the question of the management of contemporary issues by indigenous peoples. In West Kalimantan, the tendency of strengthening the implementation of the customary law has become part of the phenomenon of the community life in the province, not only by the native tribes such as the Dayak and Malay, but also the other immigrants like the Chinese. Observations and preliminary data in various places in West Kalimantan indicated that indigenous peoples have a very important role in everyday life. Zaenuddin Prasojo (2011) also reported that the revitalization of the indigenous laws and institutions of the Kebahan Dayak community in Melawi becomes one of the important factors of the identity revival of contemporary Katab Kebahan in multicultural society in Melawi. It is very important to answer the question of why the customary law of indigenous communities has increased its role significantly among the Indonesian community, particularly in West Kalimantan in the middle of the community life that is constantly changing.

In fact, we need to reveal that indigenous communities and the role of customary law have experienced serious problems in its history. The history of Indonesia pointed out that the weakening of the function of customary law to avoid saying structured extinction-- occurred as a result of the New Order's political policy that enforced the national legal system based in Jakarta (Bosko, 2006). The fact supports what is known as the deterioration of culture in which one of the consequences was the weakening of the role of customary law that took place in the New Order era (Abdullah, 2006). By looking at the historical reality, we can compare the role of indigenous peoples and indigenous judicial positions from before the New Order, during the New Order to the Reform era. The results of the comparison of the analysis on the role and participation of indigenous communities and the position of customary law are important to formulate appropriate policies in accordance with the needs of the state and society including indigenous communities in responding to the demands of 
contemporary multicultural life.

In particular, it is important to discuss and formulate clearly the phenomenon of customary law and indigenous institutions and their position in the realm of the law in Indonesia. Meanwhile, the riot cases occurring in Indonesia were heavily influenced by the unclear position of customary law and positive law which then triggered a prolonged strife and even took a huge number of casualties in West Kalimantan a few years ago.

\section{MOVEMENT OF MULTICULTURALISM}

The basic concept of multiculturalism refers to a very simple notion but contains a wide meaning which is an understanding that this world has cultural diversity. Therefore the diversity gives the implications of the enactment of the law of nature that the difference is a fact of nature that must be accepted by humans. To clearly understand the concept of multiculturalism, it is advisable to start from the literal meaning of multiculturalism and discuss the use of the term in each context.

Literally, multiculturalism consists of the prefix multi (opposite of single) which means many or more than one, and culture which means socially transmitted behavior patterns, arts, beliefs, institutions, and all other products of human work and thought or custom shapes formed socially and ism which means belief or a belief system. Thus the concept of multiculturalism can mean a doctrine which holds a general principle that this world is made up of many different cultures. The implied meaning is that all cultures in the world have the same rights and obligations in building a good community in a multicultural framework. Therefore, the literal meaning also indicates that the multiculturalism movement is a movement that brings about the fact that human culture is indeed composed of various cultures requiring us to respect each other's culture for the creation of harmony in community life.

In the sociological and anthropological context, the notion of multiculturalism also gives emphasis on the plurality of human culture. An example of the concept of multiculturalism was defined by Berry (quoted by Fatmawati, 2009: 169 ) as plural society that consists of at least a community in general, various groups that are acculturated and the government that respects plurality and allows it to exist peacefully. This view is actually in line with what is described by C.W. Watson (2000: 2-3) who explains that the multiculturalism movement focuses on the plurality of human cultures and the equality of cultures. Multiculturalism movement not only refers to awareness of the existence of the plurality of cultures but also to the fact that the culture of each human 
being is the result of shared experience in the life of society.

What about the movement of multiculturalism in developed countries? In the United States the movement of multiculturalism began long ago. One of the milestones was the movement Martin Luther King fought. King's anti slavery movement has changed the face of America significantly. In his well-known speech "I have a dream" in Washington D.C., King was a black American who had succeeded in opening the eyes of the world to the equality of every human culture and civilization in the world. How about Indonesia? According to Hamid Darmadi (2009: 95-96), actually a multicultural awareness in Indonesia has emerged since the Unitary State of the Republic of Indonesia was founded in 1945. However, Indonesia went through bitter experience at the time of the New Order that suppressed the development of multiculturalism. The Regime imposed monoculturalism with the government becoming so powerful that the awareness of multiculturalism had almost no space to grow.

\section{CULTURAL REVITALIZATION IN RESPONSE TO CONTEMPORARY CONDITIONS}

Seeing the way local communities are facing the challenges of globalization, the influence of industrialization and economic competition in this modern world, Irwan Abdullah (2006) explained that the continuity of customs and customary law are very vulnerable in the life of modern society, even though indigenous peoples live in the rural areas. This is due to the influence of globalization happens not only in urban areas but also in the interior regions such as Papua and Kalimantan. Abdullah cited the theory of threats and challenges of globalization, industrialization, and economy put forward by Featherstone (1991) opinion and Hannerz (1996) who argued that the threats have forced humans to use the survival and accumulative strategies. On the one hand, people are pressured by economic necessity as a result of the insistence of the need and a new lifestyle brought by globalization and industrialization. On the other hand, they are required to survive in order to compete in a globalized world based on free competition.

The attitude that results from the pressure described earlier suggests that the indigenous peoples tend to revitalize the customary law, for instance in the way they manage the forest and the traditional art that become part of their cultural treasure. This means that the tendency to revitalize customary law shown by the indigenous communities is as a form of response to the contemporary situation they are facing, including those in Indonesia, especially in West Kalimantan in the context of this paper. In this light, to understand and respond to cultural revitalization by indigenous communities 
should not be separated from the conditions that encourage the emergence of the contemporary situation in a variety of fields including social, economic, political and technological information development.

In addition, in response to contemporary conditions, as argued by Syarif Ibrahim Alqadrie (1990), the attitude of strengthening the role of the customary law can also be seen as a cultural resistance movement through strengthening the implementation of customary law. When indigenous peoples were squeezed by the pressure from the outside, they will respond by using the customary law which serves as the most possible social and moral strength to fortify themselves from the effects of globalization. The attitude of cultural resistance through the strengthening of the implementation of this law should be a concern for legal practitioners and law makers to consider in an attempt to revive the supremacy of law in the life of a nation. It is important to prevent the misinterpretation of "the independence of law" by the irresponsible parties who use customary law for personal or a certain group's interests.

\section{CUSTOMARY LAW IN A MULTICULTURAL SOCIETY}

Jamie Davidson and David Henley (2008) explained that the indigenous movement in Indonesia is driven by several factors i.e. the international influence, legacy of ideology and opportunities provided by the reform era. Furthermore they provided detailed reviews that the opportunities in the reform era have been used by the indigenous communities to use customary law to request the return of their rights such as the management of natural resources and the political issues such as local leadership of the community that in the era of the New Order were never realized. Under such circumstances, especially the latter, the indigenous communities have the power to revive customary law and even place it above the positive law. In addition to the multicultural movement after the fall of the New Order Regime and the international influence through globalization, this condition is also driven by internal factors i.e. the function and role of customary law which are so significant in the life of the indigenous communities.

Customs have strategic functions in the life of indigenous peoples. According to Rafael Edy Bosko (2006), customs can serve as a symbol of the identity of the owner of the community capable of representing many aspects of life. Therefore, Bosko argued that to understanding indigenous communities and their problems, one can make use of studies on customs. In addition, based on the philosophy of life, customs are also a result of the representation of indigenous needs in daily life including the concept of communal ownership of traditional objects such as land and forests. The theory of functions and the 
role of customs are necessary to understand the position of customary law of indigenous peoples and to seek answers to the phenomenon of the rise the role of customary law among indigenous communities. Thus, it is clear that the phenomenon of the rise of the role of customs and indigenous institutions or customary law is the response of the contemporary condition that requires the indigenous peoples to show their existence and protect the wealth of cultural and natural environment they have.

In addition, Tania Murrai and Li (2001) explained that the role of indigenous communities in the environmental sustainability proves to be very important for the people whose livelihood depends on the nature. Li based this theory on her research on local communities in Indonesia particularly in Papua and Kalimantan. In its function and role in preserving the nature, customs also have the concept of disaster and environmental management. Selton H. Davis and Alaka Wali (1994) argued that forest management based on the system owned by local communities can become a good alternative and beneficial to the prevention of environmental damage. This opinion is based on what local people in Latin America has been achieved, especially in terms of increased awareness of the importance of thinking and are doing to improve the management of natural resources which have increasingly more severe damage as a result of the excessive exploitation by irresponsible parties. This includes elements of culture, beliefs, and customs and customary law that have been proven to be effective to improve the management of forest and increase the prosperity of the surrounding community. Learning from the experience of Latin America, it appears that the elements of environmental damage are the seeds of disaster for indigenous communities to the attention of the continuity of their life. This means that the need to survive from the extinction is one of the factors that encourages the emergence of indigenous movements in response to the influx of the threats resulting from a process of globalization that brings a multicultural movement.

However, survival factors and other things that drive the movement of indigenous communities should not cause the advocacy of movement of indigenous communities to be too liberal. In some cases, such as the need for immediate revitalization and restitution of the Dayak culture, Giring (2008) in his study explained about the advocacy of the rights of indigenous communities from the experience of the Dayak people. Of course the customary law advocacy process is important to find an appropriate format so that the efforts to make law as the main guidelines for the community and the state become a basis to respond to issues of law enforcement in a multicultural society in Indonesia. One alternative to consider is to place customary law as a 
pioneer in the positive law as being developed in several countries such as the United States and New Zealand with a concept of Restorative Justice.

We need to, first, look at the legal system in Indonesia's national law. It includes Criminal Code which actually consists of three sub systems i.e. the customary law, the law inherited from the colonial Dutch and the new national law. Benny S. Tabalujan maintained as follows:

"The Indonesian legal system is complex because it is a confluence of three distinct systems. Prior to the first appearance of Dutch traders and colonists in the late 16th century and early 17 th century, indigenous kingdoms prevailed and applied a system of adat (customary) law. Dutch presence and subsequent colonization during the next 350 years until the end of World War II left a legacy of Dutch colonial law. A number of such colonial legislation continues to apply today. Subsequently, after Indonesian declared independence on 17 August 1945, the Indonesian authorities began creating a national legal system based on Indonesian precepts of law and justice. These three strands of adat law, Dutch colonial law and national law co-exist in modern Indonesia. For example, commercial law is grounded upon the Commercial Code 1847 (Kitab Undang-Undang Hukum Dagang or Wetboek van Koophandel), a relic of the colonial period. However, commercial law is also supplemented by a large number of new laws enacted since independence. They include the Banking Law 1992 (amended in 1998), Company Law 1995, Capital Market Law 1995, Antimonopoly Law 1999 and the Oil \& Natural Gas Law 2001. Adat law is less conspicuous. However, some adat principles such as "consensus through decision making" (musyawarah untuk mufakat) appear in modern Indonesian legislation" (Tabalujan, 2005:1).

By looking at the position, an alternative implementation of customary law in the national system such as the concept offered in the implementation of Restorative Justice in the United States and New Zealand can be applied with a model adapted to Indonesia's conditions with regard to customary law of the indigenous communities in the country. The Model can be in the form of giving the authority of the implementation of customary law to the respective indigenous communities through legitimate law in matters regulated by customary law. Thus, customary law is given a mandate that has legal power that binds the members of the local indigenous communities.

\section{CLOSING REMARKS}

Indigenous movements emerge as a response to a multicultural awareness that 
inspires those whose basic rights suppressed. The awareness of awakening and efforts in reviving the customary law of indigenous communities in Indonesia has been going on for a long time, at least since the end of the reign of the New Order Regime. The appearance of the embryo received a fresh breeze in the Reform Era that gave the opportunity for the awakening of the minority over the hegemony of the government that was supported by a culture of militarism and dictatorship. The current movement of the awareness of local communities has become proof of the existence of the multicultural movement that brings a mission of freedom over the development of a plural society that respects the freedom of other cultures in a balanced way.

Customary law as one of the authentic capital of indigenous communities is a reflection of the existence of multicultural principles that have actually existed and been part of the Indonesian society, more specifically in the Western Kalimantan. The role of customary law in the life of the multicultural society in the modern era should be aligned with the history of the Unitary State of the Republic of Indonesia which was founded by the best children of the nations that agreed to establish a state based on the supremacy of law. Customary law is part of the state law. Therefore, we need to think of a proper format for the position and the role of customary law in the Indonesian legal system for the prosperity of society based on equality before the law and justice in accordance with the ideals of the nation.

As an alternative as to where we might put the position of customary law in a multicultural nation today, we can take the example from patterns made by several countries that have adopted Restorative Justice systems with the main principles that the law is a device to resolve the problems in a just and fair way and with the awareness to return all the problems to the perspective of the law for the common good.

\section{BIBLIOGRAPHY}

Abdullah, Irwan. 2006. Konstruksi dan Reproduksi Kebudayaan. Yogyakarta: Pustaka Pelajar.

Alqadrie, Syarif Ibrahim. 2008. Matahari Akan Terbit di Barat. Pontianak: Yayasan Insan Cita Kalimantan Barat.

Bamba, John. 2004. "Globalization, state incapacity and the future of indigenous peoples in Indonesia." Dalam Kumpulan makalah John Bamba. Pontianak: Institute Dayakologi. Hal 28-46.

Bosko, R. E. 2006. Hak-Hak Masyarakat Adat dalam Konteks Pengelolaan Sumber Daya Alam. Jakarta: Elsam. 
Bowen, John R. 2000. 'Should we have a universal concept of 'indigenous peoples' rights'?: ethnicity and essentialism in the twenty-first century'. Anthropology Today, Vol. 16, No. 4 pp. 12-16

Darmadi, Hamid. 2009. "Multikulturalisme dan pendidikan multikultural "dalam Yohanes Bahari \& Ismail Ruslan. Multikulturalisme dalam sorotan. Pontianak: STAIN Pontianak Press. Hal: 83-106

Davidson, Jamie \& David Henley. 2008. "In the name of Adat: regional perspective in reform, tradition and democracy in Indonesia" dalam Modern Asian studies Vol. 42. no. 4 p: 815-852

Davidson, Jamie S. (2003). "Primitive politics": The rise and fall of the Dayak Unity Party in West Kalimantan." Asia Research Institute working paper series. No.9 Oktober 2003. Retrieved on May 27, 2009 from http:// www.ari.nus.edu.sg/docs/wps/wps03_009.pdf

2007. "Culture and rights in ethnic violence." dalam Davidson, Jamie Seth and Henley, David (ed). The revival of tradition in Indonesian politics: the deployments of adat from colonialism to indegenism. London dan New York: Routledge. Hal: 224-246.

Davis, Slton H. dan Alaka Wali. 1994. "Indigenous land tenure and tropical forest management in Latin America." Dalam Ambio, Vol. 23, No. 8 (Dec., 1994), pp. 485-490.

Fatmawati. 2009. "Harmonisasi antar umat beragama dalam masyarakat multi etnik melalui pendekatan multiculturalism" dalam Yohanes Bahari \& Ismail Ruslan. Multikulturalisme dalam sorotan. Pontianak: STAIN Pontianak Press. Hal: 158-185.

Featherstone, Mike. 1991. Consumer Culture and Postmodernism. London: Sage Publications.

Giring. 2008. "Advokasi hak-hak masyarakat adat: pengalam dari tanah Dayak" diunduh dari laman Institute Dayakologi Pontianak pada tanggal 2 September 2008.

Hannerz, Ulf. 1992. Cultural Complexity. New York: Columbia University Press.

Kingsbury, Benedict. 1998. "Indigenous peoples" in international law: a constructivist approach to the Asian controversy.' The American Journal of International Law, Vol. 92, No. 3 pp. 414-457

Li, Tania Murray. 2007. "Adat in Central Sulawesi: contemporary deployments." dalam Davidson, Jamie Seth and Henley, David (ed). The revival of tradition in Indonesian politics: the deployments of adat from colonialism to indegenism. London dan New York: Routledge. Hal: 337-369.

Lontaan, J. U. 1975. Sejarah-Hukum Adat dan Adat Istiadat Kalimantan-Barat. 
Pontianak: Pemda Tingkat I Kalbar (Dicetak oleh Offset Bumirestu Jakarta).

Prasojo, Zaenuddin Hudi. 2008. Riots on the News in West Borneo. Pontianak: STAIN Press.

------. 2011. "Indigenous community identity within Muslim societies in Indonesia: a study of Katab Kebahan Dayak in West Borneo." Dalam Oxford Journal of Islamic Studies. No.22. Vol.1. Hal: 50-65

Tabalujan, B. S. (2005). “The Indonesian legal system: An overview. In Indobizlow.com retrieved on December 9, 2007 from http://www.indobizlaw. com/forms/IDLegalOverview.pdf

Watson, C. W. 2000. Multiculturalism. Buckingham-Philadelphia: Open University Press.

Yakob, Said and Prasojo, Zaenuddin Hudi. 2009. Materi adat dan hukum adat istiadat warga Katab Kebahan wilayah Nanga Pinoh. Pontianak: STAIN Press.

Zehr, Howard. 1990. Changing Lenses: a new focus for crime and justice. Scottsdale: Herald Press. 